\title{
Extended Intergroup Contact and Outgroup Attitude of Students in Public and Religious Homogeneous Schools: Understanding the Mediating Role of Ingroup Norms, Outgroup Norms, and Intergroup Anxiety
}

\author{
Whinda Yustisia ${ }^{1}$, Joevarian Hudijana ${ }^{2}$ \\ 1,2Faculty of Psychology, Universitas Indonesia \\ Submitted 5 January 2019 Accepted 22 February 2021 Published 26 April 2021
}

\begin{abstract}
Previous studies had shown the benefits of extended intergroup contact for outgroup attitude, mainly when direct intergroup contact is blocked. However, there have not studies that attempt to directly compare the role of extended contact in outgroup attitude across different contexts. The present study aimed to fill the gap by examining the relationship of extended intergroup contact and outgroup attitude in three different contexts: public schools, moderate Islamic Boarding School, and fundamentalist Islamic Boarding School. These schools differ in the level of group heterogeneity. Possible mechanisms that could explain the relationship were also examined: ingroup norms, outgroup norms, and intergroup anxiety. Two correlational studies were conducted to test the hypotheses-study 1 employed 126 Muslim public high school students employed as participants, study 2 employed 112 participants from a more fundamentalist Islamic Boarding School and 230 participants from a more moderate Islamic Boarding Schools. Across studies, we found evidence that extended intergroup contact indirectly predicted outgroup attitude. However, different social contexts involve different mechanisms. This difference is attributed to direct intergroup contact.
\end{abstract}

Keywords: extended intergroup contact; ingroup norms; intergroup anxiety; outgroup attitude; outgroup norms

Do heterogeneous groups provide a better environment in promoting positive intergroup attitudes than homogenous ones? There has been extensive debate in addressing this question. Some studies indicate that diversity has an association with lower trust (Alesina \& La Ferrara, 2005; Dinesen \& Sønderskov, 2012; Putnam, 2007), increases prejudice and discrimination in majority toward minority (Taylor, 1998), notably when the percentage of minority exceeded $35 \%$ (Forman, 2003). These studies mainly rely on intergroup threats theory, which argues that the presence of minorities would be a threat for the majority, and prejudice is a response to that perception of threat (see Wagner et al. 2006). Meanwhile, the other body of research argues that heterogeneity is indeed beneficial to 
build a harmonious society as long as people in it have a positive intergroup contact (see Hewstone, 2009, for a review; see also Christ et al., 2010; McLaren, 2003; Stolle et al., 2008; Yustisia et al., 2020). The effects are particularly stronger when individuals engage in direct intergroup contact, such as through cross-group friendship (e.g., Paolini et al., 2004; Tropp et al., 2011; Yustisia, 2016).

Despite its positive impact, sometimes heterogeneity environments are less likely to occur; for example, people in the conflict areas who live in segregated areas (see Dovidio, Eller, Hewstone, 2011 for a review). In this context, if intergroup contact is possible and positively developed, people could still gain benefits from it. For example, a study in the terrorism context showed that positive intergroup contact experience among terrorist detainees in Indonesia can increase perspective taking ability and develop an alternative social identity (Milla \& Umam, 2019). However, direct intergroup contact is vulnerable to be influenced by negative emotions that are likely to emerge during the interaction process, such as the anxiety feeling, discomfort, and fear of showing prejudice or intolerance (Wright et al., 1997), in particular when group membership group is salience.

Moving from these constraints, Wright et al. (1997) proposed the importance of extended intergroup contact. The idea is that the mere knowledge that an ingroup has outgroup friends could lead to a positive intergroup attitude. When individuals engage in direct intergroup contact, they tend to focus on the individuating features of the contact (Wright et al., 2008). Meanwhile, in extended contact, people are less likely to attend the personalizing information. To quickly understand the intergroup contact, an observer in an extended intergroup contact would rely on group memberships' information. Moreover, extended intergroup contact should not produce the feeling of threat or anxiety, which typically emerges when individuals involve in a direct intergroup contact. In their study, Wright et al. (1997) found that when White participants knew that at least one of their White friends have Black friends, their prejudice toward the target outgroup decreased. More importantly, the studies showed that the effects remained significant after controlling the influence of direct intergroup contact.

Some other studies supported Wright et al.' extended intergroup contact hypothesis. A study by Turner et al. (2007) in the context of White British and South Asian students' relationship, for example, found that extended intergroup contact would increase positive outgroup attitude even when the role of direct intergroup contact is controlled. The positive effects were also found in different contexts. For instance, in an educational setting in Finland (Liebkind \& McAlister, 1999) and UK (Cameron et al., 2006; Cameron et al., 2007), Catholics and Protestants relationship in Northern Ireland (Paolini et al., 2004), and Muslim-immigrant in Germany (Pettigrew et al., 2007).

Although the positive effect of extended intergroup contact has now been well documented, most of those studies were employed in the contexts where it still allows direct intergroup contact to exist. A study by Paolini et al. (2004), for example, employed Protestant and Catholic students at the University of Ulster who had between 2 and 10 outgroup friends as their participants. The initial study of extended intergroup contact by 
Wright et al. (1997) even employed participants from a moderately diverse environment. In those cases, there might be possibilities that the direct intergroup contact intervened with the effect of extended intergroup contact. Some studies have indeed attempted to rule out direct contact roles by controlling the quantity of direct intergroup contact (e.g., Eller et al., 2012). However, there have no studies attempting to address this matter by intentionally employing participants who come from areas with very limited outgroup contact.

To fill the gap, the present study aimed to understand the relationship of extended intergroup on outgroup attitude in a highly homogenous setting by employing students in religious homogeneous groups in Indonesia as participants. We initiated the study by replicating previous studies: examining the relationship in a more heterogeneous group context (i.e., public school). Some potential mediators were examined (e.g., Wright et al., 1997), namely ingroup norms, outgroup norms, and intergroup anxiety. As the most populous Muslim country globally, Indonesia has many religious homogeneous schools known as Pesantren. The absence of direct intergroup contact is indeed not because the schools forbid such contact, but it is more about the nature of the schools: people with other religions are not allowed admissions the school, and the students stay in the dorm that consequently limits their opportunities to engage in intergroup contact even outside of the schools.

\section{The role of mediators: How extended intergroup contact works}

Wright et al. (1997) proposed that four factors can explain the mechanism in which the effect of extended intergroup contact can influence outgroup attitude; namely intergroup anxiety, ingroup norms, outgroup norms, and the inclusion of others to self. The three potential mediators measured for the present study were intergroup anxiety, ingroup norms, and outgroup norms. These mediators were chosen given that these factors play a more important role in one of the present study contexts (i.e., Islamic boarding schools). In Islamic values, there is a belief that every religion is fundamentally different. This belief is stronger among religious individuals. Moreover, there is a strong belief that Islam is the only true religion. Therefore, participants in the Islamic boarding schools would be much less likely to include people from other religions as their ingroup and consequently their self-systems. By investigating the mediating roles of intergroup anxiety, ingroup norms, and outgroup norms, we thus can better understand the role of extended intergroup contact in the current particular context. Theoretical explanations of these three mechanisms will be explained in the following part.

\section{Intergroup anxiety}

Intergroup anxiety is generally defined as an emotion that emerges when engaging in intergroup contact due to the presumption that there will be a rejection, or the fear toward other party involved in the interaction, or they themselves will show discrimination or offensive behavior (Stephan \& Stephan, 1985). The presence of intergroup anxiety can cause people to avoid interaction between groups, and if it happens, the focus of attention 
of individuals will lead to thoughts that can confirm the initial allegations (Wilder \& Simon, 2001).

Extended intergroup contact is an alternative to intergroup contact to contain intergroup anxiety, which usually arises when engaging in direct intergroup contact. It is because the knowledge of ingroup members who interact with other groups members can reduce the negative allegations when interacting with outgroup in the future (Wright et al., 1997). It means that ingroup members' intergroup contact inform individuals that their fellow ingroup members are open to intergroup contact.

\section{Ingroup norms}

Group norm is generally defined as the unwritten rules that guide group members' behavior (Smith \& Louis, 2009). In the context of prejudice reduction, the role of social norms is not a novelty at all. In a book, Allport (1954) noted that "about half of all prejudiced attitudes are based only on the need to conform to custom." Allport explained that there are three reasons why prejudice arose as a result of social norms (Crandall \& Stangor, 2005). First, the referred group norms should make the individual have insights into who outgroup members are and how they should be treated. For example, children and parents have a shared view of particular outgroups (Degner \& Dalege, 2013). Secondly, since people in the same culture typically shared values, the same culture held the same prejudices. Third, prejudice can be created or reduced by the normative information in the ingroup.

Recent research has also supported the idea of Allport regarding the effect of norms in outgroup attitude (Crandall \& Stangor, 2005; Christ et al., 2014; Turner et al., 2008; Wright et al., 1997). In general, these studies showed that ingroup norms can act as a mediator explaining the influence of intergroup contact on outgroup attitude by providing information that there are ingroup members who have relationship with outgroup members. Then, the direct ingroup members perceive and understand the information that such intergroup contact is normative for their ingroup.

\section{Outgroup norms}

In addition to the knowledge of how members treat ingroup outgroup members, Wright et al. (1997) suggested that the influence of extended intergroup contact on outgroup attitude can also be explained by the knowledge of how outgroup members treat ingroup members. Wright et al. explained that this effect will be higher when the membership of the group is salience. For example, a Muslim knows that there are fellow Muslims who are good friends with a devout Christian. They may then interpret that the Christian friend is an example of Christian religious group members' typical characteristics: they are open to have a friendship with Muslims. This generalization would then positively influence general attitude toward the religious outgroup. 


\section{Extended intergroup contact in homogenous groups}

Although numerous studies had shown the benefits of extended intergroup contact, there are relatively few researches that examined the contextual effect of extended intergroup contact. Built on previous studies on the interaction effect of extended and direct intergroup contacts, in this study, we argue that extended intergroup contact should be more efficacious among individuals who live in a more homogeneous group than those who live in a heterogeneous group. For example, previous studies have shown that extended contact will help improve intergroup attitudes primarily when individuals have no opportunities to involve indirect intergroup contact (Christ et al., 2010; Eller et al., 2012). When the chance for direct intergroup contact is available, individuals will be more likely to rely on direct intergroup contact experiences in making a judgment about outgroups. The reason is that such direct contacts can provide more information about outgroup than extended intergroup contact. When direct intergroup contacts are blocked, individuals will learn about outgroup through their fellow ingroup members (i.e., extended intergroup contact).

Moreover, extended intergroup contact could be an option when direct intergroup contacts might be counterproductive. For example, previous experiments have shown that negative interactions (with cold and distant manner from outgroups) increased participants' ethnocentric thoughts and negative intergroup attitudes (Barlow et al., 2012; Paolini et al., 2010). In this sense, when the options of extended and direct intergroup contact are available, direct intergroup contact might undermine the effect of extended intergroup contact.

\section{Present study}

The aims of the present study were three-fold: (1) to examine the relationship extended intergroup contact on outgroup attitude outside of Western countries; (2) to understand the role of extended intergroup contact on outgroup attitude in various contexts, which differ in terms of heterogeneity; (3) to identify mediators that could explain the relationship of extended intergroup contact and outgroup attitude. To achieve these goals, two studies were conducted. In study 1, we sought to replicate previous studies in extended intergroup contact and outgroup attitude in Indonesia. In this study, we collected data in a public high school, which is more heterogeneous in terms of social diversity, and consequently, have a higher degree of intergroup contact. This group is also expected to have a lower level of religious fundamentalism for the fact that it is a public school, not a religious school. In study 2, we administered the same questionnaire to students in two homogenous Islamic schools (i.e., Pesantren). One school was known to have a more moderate interpretation of Islam. The other school was known to have a more fundamentalist interpretation of Islam. We sought to examine whether the relationship of extended intergroup contact and outgroup attitude was consistent or vary across contexts. 
We generally expected that extended intergroup contact would indirectly predict outgroup attitude in all of the contexts, but it involves different mechanisms. As suggested by previous studies (e.g., Wright et al., 1997), we hypothesized that that extended intergroup contact would be indirectly associated with outgroup attitude via ingroup norms (H1), outgroup norms (H2), and intergroup anxiety (H3) in a more heterogeneous context (i.e., public school). Meanwhile, in the context of homogenous groups, it was predicted that the mechanisms in a more fundamentalist school would be different from the one in a more moderate school. It was specifically expected that extended contact would be associated with outgroup attitude via the same mediators in a more moderate school, as found in the heterogeneous school (H4, H5, H6). Meanwhile, in a more fundamentalist school, it was hypothesized that extended group would predict outgroup attitude only via outgroup norms and intergroup anxiety (H7 \& H8), but not via ingroup norms (H9).

We predicted that group norms would not emerge as a mediator in fundamentalist Pesantren because individuals within a more religious homogeneous group tend to have stronger religious outgroup attitudes. It makes the attitude difficult to be changed. Although a supportive extended intergroup contact might change the perception of how fellow ingroup members interact with outgroup members, the norm does not necessarily lead to a more positive outgroup attitude. This expectation is built on findings in social influence theories, which suggest that attitude change can be motivated by normative concerns when individuals want to maintain positive social relationships and informational concerns when individuals want to be correct (Wood, 2000). Here, in the context of the religious intergroup relationship, attitude change will be more likely motivated by informational concerns. Individuals are motivated to behave in line with religious teachings, particularly related to interreligious relationships, rather than on their ingroup friends behavior. When individuals are motivated to be accurate and have the correct position, they tend to be more thoughtful in evaluating any attitude-relevant messages, for example, by examining the pros and cons of the messages (Lundgren \& Prislin 1998; see Wood, 2000 for review).

Finally, we expected that extended intergroup contact's total effect on outgroup attitude would be higher in the homogenous schools than in the heterogeneous group (H10). The rationale behind this expectation is that individuals from homogeneous groups tend to have a lesser opportunity to involve in direct contact. Thus, they are more likely to utilize extended intergroup contact's experiences, rather than direct intergroup contact, in making a judgment about outgroup (Eller et al., 2012).

By conducting this study, at least three benefits will be obtained. First, it would test the effects of extended intergroup contact on outgroup attitude outside of Western countries. The present study would provide the first evidence to demonstrate the role of extended intergroup contact in outgroup attitude among non-Westerners participants. Second, it would extend previous findings on extended intergroup contact to a highly homogenous group context. Finally, the first study provides evidence on how extended intergroup effects would work in homogenous Islamic schools. 


\section{Study 1}

\section{Method}

The main question of study 1 to examine whether extended intergroup contact would positively influence outgroup attitude in Indonesia, as suggested by previous studies. Three potential mediators in the extended intergroup contact hypothesis by Wright et al. (1997) were examined. To address the question, students in public schools in Depok were involved as participants. Religions of students in this school are relatively diverse, with Muslims as the majority group.

\section{Participants and procedures}

There were total 129 high school students involved as participants (female $=81$, male $=45$ ). Three participants were excluded due to missing values. Participants' ages ranged from 15-18 years old. They filled questionnaires in the class with the guidance of a research assistant. At the end of the questionnaire, participants were thanked with a small gift and debriefed.

\section{Measures}

Extended Intergroup Contact was measured by asking how many school friends, friends in their home environment, and family of participants who have friends with non-Muslims. There were four items adapted from Turner et al. (2008). For example, "How many Muslims do you know have a non-Muslim religious friend? How many Muslim friends in the cottage that you have friends with non-Muslims?). These items form a reliable scale, $\alpha$ $=0.69$.

Ingroup norms were measured by asking participants' perceptions of how their Muslim friends interact with non-Muslim. There were four items adapted from Turner et al.'s (2008). For example 'Do you think your Muslim friends would be happy to go out with someone who is non-Muslim?" and 'In general, how much do you think Muslim people like non-Muslim people?". These items form a reliable scale, $\alpha=0.72$. Items were answered using six-point rating scales ranging from 1 (strongly disagree) to 6 (strongly agree).

Outgroup norms were measured by asking participants how they perceive nonMuslim people's attitudes toward Muslims. Four items were adapted from research by Turner et al. (2008). For example: 'According to your opinion, how happy non-Muslim people friend with Muslims people?' and 'How comfortable do you think non-Muslim people friend with Muslim people?'. These items formed a reliable scale, $\alpha=0.82$. Responses were given on six-point rating scales $(1=$ strongly disagree to $6=$ strongly agree).

Intergroup Anxiety was examined by asking participants to identify what they would feel during direct intergroup contact. They were asked to indicate the extent to which they 
would feel relaxed, comfortable, happy, fearful, calm, safe, and friendly ( $\alpha=0.77$ ). These items were adapted from Stephan and Stephan (1985). Each item was answered on sixpoint rating scales $(1=$ strongly disagree to $6=$ strongly agree).

Outgroup Attitude was measured by asking participants about their general evaluation toward non-Muslim people in the semantic differential scale 1-6; such as suspicious-trustworthy, negative-positive, unfriendly-friendly, and cold-warm ( $\alpha=0.87)$. The scale was adapted from Hewstone et al. (2011).

Direct Intergroup Contact was measured as a covariate variable. Participants were asked to indicate to what extent they agree to the following statements: 'How many nonMuslim friends do you have?', 'How often do you interact with non-Muslim friends?', 'How often do you communicate with non- Muslim friends at your school?' $(\alpha=0.53)$.

\section{Results}

Descriptive statistics and intercorrelation of all variables are presented in Table 1.

Table 1

Intercorrelations, Overall Means, and Standard Deviations of Study Variables

\begin{tabular}{|c|c|c|c|c|c|c|c|c|c|}
\hline & Mean & SD & 1 & 2 & 3 & 4 & 5 & 6 & 7 \\
\hline 1. Female & - & - & 1.00 & -0.07 & $-.188^{*}$ & 0.02 & 0.05 & -0.05 & $.187^{*}$ \\
\hline 2. Age & 16.06 & 0.63 & -0.07 & 1.00 & $-.184^{*}$ & -0.11 & -0.09 & 0.03 & -0.14 \\
\hline 3. Extended Intergroup Contact & 3.78 & 0.74 & $-.188^{*}$ & $-.184^{*}$ & 1.00 & $.307^{* *}$ & $.288^{* *}$ & $-.236^{* *}$ & $.194^{*}$ \\
\hline 4. Group Norm & 4.74 & 0.52 & 0.02 & -0.11 & $.307^{* *}$ & 1.00 & $.608^{* *}$ & $-.419^{* *}$ & $.555^{* *}$ \\
\hline 5. Outgroup norms & 4.54 & 0.69 & 0.05 & -0.09 & $.288^{* *}$ & $.608^{* *}$ & 1.00 & $-.509^{* *}$ & $.582^{* *}$ \\
\hline 6. Intergroup Anxiety & 2.48 & 0.71 & -0.05 & 0.03 & $-.236^{* *}$ & $-.419^{* *}$ & $-.509^{* *}$ & 1.00 & $-.586^{* *}$ \\
\hline 7. Outgroup Attitude & 4.51 & 0.63 & $.187^{*}$ & -0.14 & $.194^{*}$ & $.555^{* *}$ & $.582^{* *}$ & $-.586^{* *}$ & 1.00 \\
\hline
\end{tabular}

Before performing a mediator analysis, regression analysis was conducted to see the unique effects of each variable. The analysis showed that at stage 1 , covariate variables explained $5 \%$ variation in outgroup attitude $\left(\mathrm{R}^{2}=.05, \mathrm{~F}(2,123)=3.06, \mathrm{p}=.05\right)$. Whereas gender $(\beta=0.16, p=0.066)$ had a marginally significant role in predicting outgroup attitude, age did not significantly predict the outcome variable $(\beta=0.22, \mathrm{p}=0.012)$. In step 2 , the model explained $52 \%$ of the variation in outgroup attitude $\left(R^{2}=0.52, F(4,119)=28.95\right.$, $\mathrm{p}<.001)$. Gender's $(\beta=0.14, \mathrm{p}=0.049)$ role remained significant and age's role remained insignificant $(\beta=-0.08, p=0.229)$. At the second stage, we found an insignificant relationship between extended intergroup contact on outgroup attitude $(\beta=-0.02, p=$ 0.76). Meanwhile, ingroup norms $(\beta=0.26, p=0.002)$, outgroup norms $(\beta=0.24, p=0.006)$, and intergroup anxiety $(\beta=-0.35, p<0.001)$ did significantly predict outgroup attitude.

Despite the insignificant direct relationship between extended intergroup contact, as suggested by Hayes (2009), a mediator analysis on the relationship of extended intergroup contact and outgroup attitude can still be performed. To examine the factors that could explain the relationship of extended intergroup contact and outgroup attitude, mediation 
analysis using SPSS macros for PROCESS (Model 4; Hayes, 2013) was performed. By using this program, the bias-corrected coefficient can be estimated from a series of 5000 bootstrap samples for any indirect effects (Preacher et al., 2007). The mediating effects are significant if the confidence interval does not contain the value 0 . In the main analysis, demographic variables (e.g., gender) were included as covariate variables.

Table 2.

Regression Coefficients, Standard Errors, and Model Summary Information for the Relationship of Extended Intergroup Contact and Outgroup Attitude via Parallel Multiple Mediators in Public School.

\begin{tabular}{|c|c|c|c|c|c|c|c|c|}
\hline \multirow{3}{*}{ Predictors } & \multicolumn{8}{|c|}{ Consequents } \\
\hline & \multicolumn{2}{|c|}{$\begin{array}{c}\text { Ingroup } \\
\text { Norms(M1) }\end{array}$} & \multicolumn{2}{|c|}{$\begin{array}{l}\text { Outgroup } \\
\text { Norms(M2) }\end{array}$} & \multicolumn{2}{|c|}{$\begin{array}{c}\text { Intergroup } \\
\text { Anxiety(M)3 } \\
\end{array}$} & \multicolumn{2}{|c|}{$\begin{array}{c}\text { Outgroup } \\
\text { Attitude(DV) }\end{array}$} \\
\hline & $\mathrm{b}(\mathrm{SE})$ & $95 \% \mathrm{CI}$ & $\mathrm{b}(\mathrm{SE})$ & $95 \% \mathrm{CI}$ & b(SE) & $95 \% \mathrm{CI}$ & $\mathrm{b}(\mathrm{SE})$ & $95 \% \mathrm{CI}$ \\
\hline Constant & $3.83(.25)$ & $\begin{array}{l}3.324 \\
4.335\end{array}$ & $3.40(.33)$ & $\begin{array}{r}2.745 \\
4.059\end{array}$ & $3.42(.34)$ & $\begin{array}{l}2.747 \\
4.110\end{array}$ & $2.69(.54)$ & $\begin{array}{l}1.634, \\
3.753\end{array}$ \\
\hline $\begin{array}{l}\text { Extended Intergroup } \\
\text { Contact }\end{array}$ & $.23(.06)$ & $\begin{array}{l}.105 \\
.347\end{array}$ & $.27(.08)$ & $\begin{array}{l}.113 \\
.428\end{array}$ & $-.22(.08)$ & $\begin{array}{l}-.389 \\
-.059\end{array}$ & $-.01(.06)$ & $\begin{array}{l}-.121, \\
.101\end{array}$ \\
\hline Ingroup Norms & - & - & - & - & - & - & $.31(.10)$ & $\begin{array}{c}116, . \\
506\end{array}$ \\
\hline Outgroup Norms & - & - & - & - & - & - & $.22(.08)$ & $\begin{array}{l}.069 \\
.382)\end{array}$ \\
\hline Intergroup Anxiety & - & - & - & - & - & - & $-.32(.07)$ & $\begin{array}{l}-.451, \\
-.186\end{array}$ \\
\hline $\begin{array}{l}\text { Gender }(1=\text { Female; } 0= \\
\text { Male })\end{array}$ & $.09(.09)$ & $\begin{array}{l}-.103 \\
.277\end{array}$ & $.16(.12)$ & $\begin{array}{l}-.091 \\
.402\end{array}$ & $-.14(.13)$ & $\begin{array}{l}-.396 \\
.119\end{array}$ & $.20(.09)$ & $\begin{array}{l}.030 \\
.372\end{array}$ \\
\hline $\begin{array}{l}\text { Extended Intergroup } \\
\text { Contact --> Ingroup } \\
\text { Norms }\end{array}$ & - & - & - & - & - & - & $.07(.03)$ & $\begin{array}{l}.021 \\
.317\end{array}$ \\
\hline $\begin{array}{l}\text { Extended Intergroup } \\
\text { Contact --> Outgroup } \\
\text { Norms }\end{array}$ & - & - & - & - & - & - & $.06(.03)$ & $\begin{array}{l}.015 \\
.116\end{array}$ \\
\hline $\begin{array}{l}\text { Extended Intergroup } \\
\text { Contact --> Intergroup } \\
\text { Anxiety }\end{array}$ & - & - & - & - & - & - & $.07(.03)$ & $\begin{array}{l}.021, \\
.138\end{array}$ \\
\hline & $\begin{array}{r}\mathrm{R}^{2}= \\
\mathrm{F}(2,125 \\
\mathrm{p}=.\end{array}$ & $\begin{array}{l}10 \\
=6.81 \\
01\end{array}$ & $\begin{array}{r}\mathrm{R}^{2}= \\
\mathrm{F}(2,125)= \\
\mathrm{p}=.003\end{array}$ & $\begin{array}{l}09 \\
=5.96, \\
\end{array}$ & $\begin{array}{r}\mathrm{R}^{2}= \\
\mathrm{F}(2,125)= \\
\mathrm{p}=.026\end{array}$ & $\begin{array}{l}.06 \\
3.77 \\
\end{array}$ & $\begin{array}{r}\mathrm{R}^{2}= \\
\mathrm{F}(2,122)= \\
\mathrm{p}<.001\end{array}$ & $\begin{array}{l}.52 \\
=25.98 \\
\end{array}$ \\
\hline
\end{tabular}

The analysis revealed that the hypotheses were supported: extended intergroup contact had significant indirect relationship with outgroup attitude via ingroup norms $(b=$ $0.07,95 \% \mathrm{CI}[0.018,0.136])$, outgroup norms $(b=0.06$, CI $[0.015,0.116])$, and intergroup anxiety $(b=0.07,95 \% C I[0.021,0.138])$. The total indirect effects were significant $(b=0.20$, $95 \%$ CI $[0.097,0.314])$. The indirect effect remained significant even after controlling the role of direct intergroup contact $(b=0.13,95 \% C I$ [0.027, 0.241]. However, in this model (direct intergroup contact was included as a covariate variable), the mediating role of 
intergroup anxiety was no longer significant $(b=0.04,95 \%$ CI $[-0.023,0.102]$. Meanwhile, other mediator variables remained significant: group norms $(b=0.05,95 \% \mathrm{CI}[0.008,0.111]$ and outgroup norms ( $b=0.04,95 \%$ CI [0.006, 0.093]).

\section{Discussion}

The results showed that extended intergroup contact did not predict outgroup attitude directly. Instead, the relationship was indirectly (fully mediated) via adherence toward ingroup norms, the obtained knowledge regarding how outgroup treat ingroup members, and the reduced anxiety toward the outgroup. Importantly, this study showed that the indirect effect remained significant even after the role of direct intergroup contact was taken into account. However, intergroup anxiety did not mediate the relationship between extended intergroup contact and outgroup attitude in such a model. Meanwhile, the mediating effects of ingroup norms and outgroup norms remained significant.

The findings that group norms, outgroup norms, and intergroup anxiety have mediation roles are consistent with previous works (Wright et al., 1997; Christ et al., 2014; Turner et al., 2008). In this sense, the knowledge that ingroup members involve in intergroup contact deems individuals that the ingroup and outgroup approve intergroup contacts and reduces intergroup anxiety. Moreover, these findings imply that extended intergroup contact could promote positive ingroup and outgroup norms and reduce intergroup anxiety even in groups with intergroup conflict history. Muslims in Indonesia have been identified to feel threatened by Christianization since colonialization (Arifianto, 2010). This sense of under threat has also been established among Christian (Mujiburrahman, 2006). The tension between Muslims and Christian continues until now in some areas (Sidel, 2007; Sterkens \& Hadiwitanto 2009). Therefore, this study supports previous studies of extended intergroup contact in the more severe conflict areas, such as in Northern Ireland (Tam et al., 2009) and Rwanda (Kellow \& Steeves, 1998).

One main novel contribution of this study is that intergroup anxiety's mediating role was insignificant when direct intergroup contact was included in the analysis as a covariate. Specifically, it was found that extended intergroup contact was significantly associated with ingroup and outgroup norms, but not intergroup anxiety. It may suggest that extended intergroup contact is adequate enough to develop outgroup and ingroup norms. However, individuals tend to rely on direct intergroup contact in evaluating intergroup anxiety. In this matter, individuals' experiences should be more informative than other persons' experiences.

Previous studies suggest that in the context where direct intergroup contact's chance is available, people will be more likely to rely on information from direct intergroup contact experience than the information from fellow ingroup members (e.g., Eller et al., 2012; Lemmer \& Wagner, 2015). This study indicates that individuals particularly utilize direct intergroup contact's experience to evaluate intergroup anxiety. The additional analysis showed that direct intergroup contact was negatively associated with intergroup anxiety. It may indicate that direct intergroup contact experiences in this study posed 
positive direct contact. To further examine if these results patterns are consistent across contexts, study 2 was conducted in more homogenous groups.

\section{Study 2}

Study 2 was conducted to address the same research question as study 1 in homogenous schools. In these schools, students' opportunity to engage in direct intergroup contact is limited. As discussed earlier, extended intergroup contact might help shape outgroup attitude in such a situation. However, the mechanisms might differ. Given that individuals in this group are likely to hold stronger ingroup norms to avoid religious intergroup contact (i.e., due to the value and historical reasons), we predicted that ingroup norms would not mediate the relationship of extended intergroup contact and outgroup attitude.

To further clarify the relationships of the main variables in a homogenous group context, we collected data from two Islamic Boarding Schools (Pesantren), with different characteristics. The first school had a more fundamentalist teaching than typical Pesantren in Indonesia. Few terrorism actors were identified as a graduate from this Pesantren. Fundamentalist pesantren might arguably exert higher exclusivity and less intergroup contact (directly or indirectly), analogous with some radical extremist groups (Iannaccone \& Berman, 2006). The second school had a more moderate Islam view since they hold Nadhatul Ulama (NU) teachings. NU is an Islamic organization that always attempts to spread moderate Islamic teachings in Indonesia by accommodating local values.

\section{Method}

\section{Participants and procedures}

Among 342 participants, 191 were female. Their ages ranged from 12-19 years old ( $\mathrm{M}=$ $15.69, \mathrm{SD}=1.66)$. They filled a questionnaire with the research assistant's guidance in class in their Pesantren. Upon completion, they were debriefed and thanked with a small gift.

\section{Measures}

All materials employed in study 2 were exactly the same as study 1 . In present study contexts, reliability analysis yielded alpha Cronbach as follow: extended intergroup $\alpha=$ 0.63 , group norm $\alpha=0.71$, outgroup norms $\alpha=0.87$, intergroup anxiety $\alpha=0.77$, outgroup attitude $\alpha=0.80$, direct intergroup contact $\alpha=0.71$.

\section{Results}

Before the main analysis, mean comparisons were first conducted to test the basic assumptions on the nature between Pesantren and public school in terms of variables 
examined in the present study. As presented in the table below, the analysis revealed a significant difference in the mean score of the ingroup norms, outgroup norms, intergroup anxiety, and outgroup attitude as a function of school types. As expected, participants in moderate Pesantren had more positive ingroup norms $(\mathrm{M}=3.08 \mathrm{SD}=0.95)$ than those in the fundamentalist school $(\mathrm{M}=2.87, \mathrm{SD}=0.87)$ slightly, but it is still much less supportive than what participants in had Public School had $(\mathrm{M}=4.75, \mathrm{SD}=51)$. The difference between the moderate and fundamentalist Pesantren was significant $(\mathrm{t}(340)=$ 2.195, $\mathrm{p}=0.029)$. Additionally, the group norm difference between the three groups was also found to be statistically significant $(F(2,457)=188.92, \mathrm{p}<0.001)$.

Similar patterns were found in other variables. In relation to outgroup norms, participants in the fundamentalist Pesantren had less positive outgroup norms ( $M=2.93$, $\mathrm{SD}=1.20)$ than those in the moderate Pesantren $(\mathrm{M}=3.18, \mathrm{SD}=1.09)$ and those in Public shool $(\mathrm{M}=4.53, \mathrm{SD}=0.64), \mathrm{F}(2,457)=85.25, \mathrm{p}<0.001$. It indicated that the fundamentalist Pesantren had the least positive perception of how their religious outgroup members might want to interact with them. In terms of intergroup anxiety, it was also found that those in the fundamentalist Pesantren were the most anxious group when imagining the interaction with religious outgroup members $(\mathrm{M}=3.77, \mathrm{SD}=0.99)$ compared to those in the moderate Pesantren $(\mathrm{M}=3.44, \mathrm{SD}=1.16)$ and public school $(\mathrm{M}=2.45, \mathrm{SD}=0.67), \mathrm{F}(2,457)=$ 49.94, $\mathrm{p}<0.001$. It was also found that those in the fundamentalist Pesantren had a slightly higher extended intergroup contact $(\mathrm{M}=1.99, \mathrm{SD}=0.74)$ than those in the moderate Pesantren $(\mathrm{M}=1.89, \mathrm{SD}=0.70)$ but the difference was not significant $(\mathrm{t}(340)=1.31, \mathrm{p}=0.191)$. In comparison to public school $(\mathrm{M}=3.41, \mathrm{SD}=3.01)$, extended intergroup contact in Pesantren would then be significantly much lower $(\mathrm{F}(2,457)=185.44, \mathrm{p}<0.001)$. In terms of outgroup attitude, analysis indicated that participants from the fundamentalist one has the least positive attitude $(\mathrm{M}=3.08, \mathrm{SD}=0.99)$ in comparison with the moderate one $(\mathrm{M}=$ 3.36, $\mathrm{SD}=1.02)$, and public schools $(\mathrm{M}=4.50, \mathrm{SD}=0.63), \mathrm{F}(2,457)=68.70, \mathrm{p}<0.001$. Finally, the analysis showed that students in public schools had a more frequent direct intergroup contact $(\mathrm{M}=3.58, \mathrm{SD}=0.66)$ than this in moderate school $(\mathrm{M}=1.56, \mathrm{SD}=0.68)$ and fundamentalist school $(\mathrm{M}=1.45, \mathrm{SD}=0.67)$. The mean differences were significant $\mathrm{F}(2$, $470)=442.37, \mathrm{p}<0.001$. The analyses of mean comparisons support the prior assumptions that there is different nature on key variables of this study in present study contexts.

Table 3.

Mean Score of All Variables in Terms of School Types

\begin{tabular}{lcccccccccc}
\hline \multirow{2}{*}{ School Types } & \multicolumn{2}{c}{$\begin{array}{c}\text { Ingroup } \\
\text { norms }\end{array}$} & \multicolumn{2}{c}{$\begin{array}{c}\text { Outgroup } \\
\text { norms }\end{array}$} & \multicolumn{2}{c}{$\begin{array}{c}\text { Intergroup } \\
\text { Anxiety }\end{array}$} & \multicolumn{2}{c}{$\begin{array}{c}\text { Extended } \\
\text { Contact }\end{array}$} & \multicolumn{2}{c}{$\begin{array}{c}\text { Outgroup } \\
\text { Attitude }\end{array}$} \\
\cline { 2 - 11 } & $\mathbf{M}$ & SD & M & SD & M & SD & M & SD & M & SD \\
\hline Fundametalist Pesantren & 2.87 & .87 & 2.93 & 1.20 & 3.77 & 1.17 & 1.99 & .74 & 3.08 & .99 \\
Moderate Pesantren & 1.89 & .70 & 3.18 & 1.09 & 3.45 & 1.18 & 1.89 & .70 & 3.36 & 1.02 \\
Public School & 4.75 & .51 & 4.53 & .64 & 2.45 & .67 & 2.30 & .97 & 4.50 & .63 \\
\hline
\end{tabular}

Next, the main analysis of moderate and fundamentalist Pesantren was separately conducted. Similar to study 1 , gender was included as a covariate variable. The analysis in 
the context of moderate Pesantren showed that the hypotheses were partially supported: there were indirect effect of extended intergroup contact on outgroup attitude via ingroup norms $(b=0.05,95 \% \mathrm{CI}[0.008,0.101])$ and outgroup norms $(b=0.04,95 \% \mathrm{CI}[0.004,0.091])$, but not via intergroup anxiety $(b=0.06,95 \%$ CI [ $-0.006,0.132])$. The total indirect effect was significant $(b=0.14,95 \% \mathrm{CI}[0.048,0.247])$. These findings supported H4a, H4b, but not $\mathrm{H} 4 \mathrm{c}$. As an exploration, we include direct intergroup contact as a covariate in the next analysis. The finding showed that the result patterns remained similar: ingroup norms $(b=$ $0.04,95 \% \mathrm{CI}[0.001,0.094])$ and outgroup norms $(b=0.04,95 \% \mathrm{CI}[0.006,0.103])$ significantly mediated the relationship of extended intergroup contact and outgroup attitude; intergroup anxiety did not significantly mediate the predictor and outcome variable $(b=0.06,95 \% C I[-0.016,0.134])$. The total indirect effect remained significant $(b=0.15,95 \% C I$ $[0.044,0.261])$. In contrast to study 1 , a closer look to the role of direct intergroup contact's roles showed that direct intergroup contact was insignificantly associated with ingroup norms $(b=-0.17,95 \% C I-0.356,0.007])$, outgroup norms $(b=-0.11,95 \% C I[-0.322,0.109])$ and intergroup anxiety $(b=-0.11,95 \% \mathrm{CI}[-0.339,0.123])$.

Table 4.

Regression Coefficients, Standard Errors, and Model Summary Information for the Relationship of Extended Intergroup Contact and Outgroup Attitude via Parallel Multiple Mediators in Moderate Pesantren.

\begin{tabular}{|c|c|c|c|c|c|c|c|c|}
\hline \multirow{3}{*}{ Predictors } & \multicolumn{8}{|c|}{ Consequents } \\
\hline & \multicolumn{2}{|c|}{$\begin{array}{c}\text { Ingroup } \\
\text { Norms(M1) }\end{array}$} & \multicolumn{2}{|c|}{$\begin{array}{l}\text { Outgroup } \\
\text { Norms(M2) }\end{array}$} & \multicolumn{2}{|c|}{$\begin{array}{c}\text { Intergroup } \\
\text { Anxiety(M)3 }\end{array}$} & \multicolumn{2}{|c|}{$\begin{array}{c}\text { Outgroup } \\
\text { Attitude(DV) }\end{array}$} \\
\hline & $\mathrm{b}(\mathrm{SE})$ & $95 \% \mathrm{CI}$ & $\overline{b(S E)}$ & $\begin{array}{c}95 \% \mathrm{C} \\
\mathrm{I}\end{array}$ & $\mathbf{b}(\mathrm{SE})$ & $95 \% \mathrm{CI}$ & $\overline{b(S E)}$ & $95 \% \mathrm{CI}$ \\
\hline Constant & $2.36(.17)$ & $\begin{array}{l}2.011 \\
2.705\end{array}$ & $2.49(.21)$ & $\begin{array}{l}2.084 \\
2.905\end{array}$ & $3.65(.220$ & $\begin{array}{l}3.204 \\
4.086\end{array}$ & $3.73(.34)$ & $\begin{array}{l}3.058 \\
4.396\end{array}$ \\
\hline $\begin{array}{l}\text { Extended Intergroup } \\
\text { Contact }\end{array}$ & $.24(.07)$ & $\begin{array}{l}.097 \\
.393\end{array}$ & $.25(.09)$ & $\begin{array}{l}.081 \\
.428\end{array}$ & $-.17(.09)$ & $\begin{array}{c}-.355 \\
.019\end{array}$ & $-.08(.07)$ & $\begin{array}{c}-.227 \\
.064\end{array}$ \\
\hline Ingroup Norms & - & - & - & - & - & - & $.19(.07)$ & $\begin{array}{l}.052 \\
.334\end{array}$ \\
\hline Outgroup Norms & - & - & - & - & - & - & $.15(.06)$ & $\begin{array}{l}.035 \\
.273\end{array}$ \\
\hline Intergroup Anxiety & - & - & - & - & - & - & $-.34(.05)$ & $\begin{array}{c}-.445,- \\
.238\end{array}$ \\
\hline $\begin{array}{l}\text { Gender ( } 1=\text { Female; } 0= \\
\text { Male) }\end{array}$ & $.49(.12)$ & $\begin{array}{l}.258 \\
.735\end{array}$ & $.38(.14)$ & $\begin{array}{l}.102, \\
.665\end{array}$ & $.33(.15)$ & $\begin{array}{l}.027 \\
.632\end{array}$ & $-.08(.07)$ & $\begin{array}{c}-.229 \\
.064\end{array}$ \\
\hline $\begin{array}{l}\text { Extended Intergroup } \\
\text { Contact --> Ingroup } \\
\text { Norms }\end{array}$ & - & - & - & - & - & - & $.04(.05)$ & $\begin{array}{l}.046 \\
.235\end{array}$ \\
\hline $\begin{array}{l}\text { Extended Intergroup } \\
\text { Contact --> Outgroup } \\
\text { Norms }\end{array}$ & - & - & - & - & - & - & $.04(.02)$ & $\begin{array}{l}.003 \\
.088\end{array}$ \\
\hline Extended Intergroup & - & - & - & - & - & - & $.06(.03)$ & -.007 \\
\hline
\end{tabular}




\begin{tabular}{lcccc}
\hline $\begin{array}{l}\text { Contact -- Intergroup } \\
\text { Anxiety }\end{array}$ & \multicolumn{3}{c}{} & .129 \\
& $\mathrm{R}^{2}=.11$ & $\mathrm{R}^{2}=.06$ & $\mathrm{R}^{2}=.04$ & $\mathrm{R}^{2}=.28$ \\
& $\mathrm{~F}(3,226)=9.07$, & $\mathrm{F}(3,226)=5.16$, & $\mathrm{F}(3,226)=2.82$, & $\mathrm{F}(6,223)=15.32$, \\
& $\mathrm{p}<.001$ & $\mathrm{p}=.002$ & $\mathrm{p}=.04$ & $\mathrm{p}<.001$ \\
\hline
\end{tabular}

Analysis in the context of fundamentalist Pesantren revealed that the hypotheses were also partly supported: extended intergroup contact indirectly predicted outgroup attitude via outgroup norms $(b=0.09,95 \%$ CI $[0.015,0.204])$ and intergroup anxiety $(b=$ $0.13,95 \% \mathrm{CI}[0.036,0.129])$ but not via ingroup norms ( $b=0.03, \mathrm{CI}[-0.044,0.108])$. The total indirect effect was significant $(b=0.23,95 \% C I[0.099,0.375])$. These findings supported $\mathrm{H} 4 \mathrm{a}, \mathrm{H} 4 \mathrm{~b}$, and $\mathrm{H} 4 \mathrm{c}$. When direct intergroup contact was included in the analysis as a covariate variable, the total indirect effect remained significant $(b=0.17,95 \% C I$ [0.038, $0.224])$. The mediating role of ingroup norms remained insignificant $(b=0.03,95 \% C I$ [$0.042,0.113])$ and outgroup norms remained significant $(b=0.07,95 \% \mathrm{CI}[0.007,0.188])$. Consistent with the finding in the public-school context, in this model, intergroup anxiety's mediating role was no longer significant ( $b=0.09,95 \%$ CI $[-0.098,0.416])$. Similar to findings in moderate Pesantren, direct intergroup contact was insignificantly associated with ingroup norms $(b=0.05,95 \%$ CI $[-0.210,0.308])$, outgroup norms $(b=0.24,95 \% C I$ [$0.110,0.599])$ and intergroup anxiety $(b=-0.27,95 \% C I[-0.634,0.079])$ in this group.

Table 5.

Regression Coefficients, Standard Errors, and Model Summary Information for the Relationship of Extended Intergroup Contact and Outgroup Attitude via Parallel Multiple Mediators in Fundamentalist Pesantren.

\begin{tabular}{|c|c|c|c|c|c|c|c|c|}
\hline \multirow{4}{*}{ Predictors } & \multicolumn{8}{|c|}{ Consequent } \\
\hline & \multicolumn{2}{|c|}{$\begin{array}{c}\text { Ingroup } \\
\text { Norms(M1) }\end{array}$} & \multicolumn{2}{|c|}{$\begin{array}{l}\text { Outgroup } \\
\text { Norms(M2) }\end{array}$} & \multicolumn{2}{|c|}{$\begin{array}{c}\text { Intergroup } \\
\text { Anxiety(M)3 }\end{array}$} & \multicolumn{2}{|c|}{$\begin{array}{c}\text { Outgroup } \\
\text { Attitude(DV) }\end{array}$} \\
\hline & & $95 \% \mathrm{C}$ & & $95 \% \mathrm{C}$ & & & & $95 \% \mathrm{C}$ \\
\hline & $\mathbf{b}(\mathrm{SE})$ & I & b(SE) & I & $\mathbf{b}(\mathrm{SE})$ & $95 \% \mathrm{CI}$ & $\mathbf{b}(\mathrm{SE})$ & $\mathbf{I}$ \\
\hline Constant & $2.13(.21)$ & $\begin{array}{l}1.712 \\
2.555\end{array}$ & $1.86(.29)$ & $\begin{array}{l}1.277 \\
2.441\end{array}$ & $4.58(.29)$ & $4.000,5.172$ & $3.43(.51)$ & $\begin{array}{l}2.433, \\
4.427\end{array}$ \\
\hline $\begin{array}{l}\text { Extended Intergroup } \\
\text { Contact }\end{array}$ & $.32(.09)$ & $\begin{array}{l}.131 \\
.493\end{array}$ & $.47(.13)$ & $\begin{array}{l}.222 \\
.721\end{array}$ & $-.34(.13)$ & $-.597,-.960$ & $.04(.09)$ & $\begin{array}{l}-.152, \\
.235\end{array}$ \\
\hline Ingroup Norms & - & - & - & - & - & - & $.09(.10)$ & $\begin{array}{r}-.106, \\
.292\end{array}$ \\
\hline Outgroup Norms & - & - & - & - & - & - & $.19(.07)$ & $\begin{array}{l}.044, \\
.332\end{array}$ \\
\hline Intergroup Anxiety & - & - & - & - & - & - & $-.36(.07)$ & $\begin{array}{l}-.499 \\
-.213\end{array}$ \\
\hline $\begin{array}{l}\text { Gender }(1=\text { Female; } \\
0=\text { Male })\end{array}$ & $.13(.16)$ & $\begin{array}{c}-.183 \\
.447\end{array}$ & $.12(.22)$ & $\begin{array}{c}-.317 \\
.551\end{array}$ & $-.12(.22)$ & $-.559, .314$ & $.18(.16)$ & $\begin{array}{c}-.125, \\
.495\end{array}$ \\
\hline $\begin{array}{l}\text { Extended Intergroup } \\
\text { Contact -->Ingroup Norms }\end{array}$ & - & - & - & - & - & - & $.03(.07)$ & $\begin{array}{c}-.044, \\
.108\end{array}$ \\
\hline $\begin{array}{l}\text { Extended Intergroup } \\
\text { Contact --> Outgroup }\end{array}$ & - & - & - & - & - & - & $.09(.05)$ & $\begin{array}{l}.015, \\
.204\end{array}$ \\
\hline
\end{tabular}




\begin{tabular}{|c|c|c|c|c|}
\hline $\begin{array}{l}\text { Norms } \\
\text { Extended Intergroup } \\
\text { Contact --> Intergroup } \\
\text { Anxiety }\end{array}$ & - & - & - & $\begin{array}{l}.036 \\
.129\end{array}$ \\
\hline & $\begin{array}{c}\mathrm{R}^{2}=.11 \\
\mathrm{~F}(2,109)=6.93 \\
\mathrm{p}=.002\end{array}$ & $\begin{array}{c}\mathrm{R}^{2}=.12 \\
\mathrm{~F}(2,109)=7.77 \\
\mathrm{p}=.001\end{array}$ & $\begin{array}{c}\mathrm{R}^{2}=.07 \\
\mathrm{~F}(2,109)=4.32, \mathrm{p}=.016\end{array}$ & $\begin{array}{c}\mathrm{R}^{2}=.38 \\
\mathrm{~F}(5,106)=12.81, \\
\mathrm{p}<.001\end{array}$ \\
\hline
\end{tabular}

\section{Discussion}

Study 2 was conducted to examine the relationship of extended intergroup contact and outgroup attitude in more homogenous groups. We administered a set of questionnaires to students from two Islamic Boarding Schools (Pesantren) in Indonesia: one school has a more moderate interpretation of Islam, and the other school has a more fundamentalist interpretation of Islam. The findings supported $\mathrm{H} 4$ and $\mathrm{H} 5$, whereby extended intergroup indirectly predict outgroup attitude via ingroup and outgroup norms. However, it rejected H6: we did not find a significant mediation effect of intergroup anxiety. While the findings partly supported hypotheses in the more moderate school, we found all hypotheses were supported in more fundamentalist Islamic Boarding Schools. In such a school, we found that extended intergroup contact indirectly predicted outgroup attitude via outgroup norms (H8) and intergroup anxiety (H9), but not via ingroup norms (H7). We will discuss each one of these findings.

First, we found significant mediation effects of ingroup norms and outgroup norms in the more moderate Pesantren. These findings are consistent with the finding in study 1, which was conducted in the public school's school, where the opportunity to have direct intergroup contact is higher and religious fundamentalism is typically lower. However, we found an insignificant mediation effect of intergroup anxiety. To understand the insignificant mediation effect of intergroup anxiety, we explored direct intergroup contact's possible role. The idea is that participants in this group, to some extent, might have direct intergroup contact experiences, at least in comparison to those in a more fundamentalist school. The mean comparison analysis supported this assumption. Therefore, the insignificant relationship of extended intergroup contact and intergroup anxiety might be attributed to direct intergroup contact experiences. If it were the case, as found in study 1, direct intergroup contact would have a significant association with intergroup anxiety. However, further analysis showed that direct intergroup contact was not significantly associated with mediator variables. Therefore, it may indicate that the direct intergroup contact experiences had negative qualities. Therefore, it has a minimal role in shaping extended intergroup contact influence on the outcome variables.

Second, in the context of a more fundamentalist group, we found a significant mediation effect of outgroup norms and intergroup anxiety, but not ingroup norms. Concerning ingroup norms, we specifically found that extended contact may influence ingroup norms, but this norm did not influence the outgroup attitude. We did not find this pattern in the moderate Pesantren. This finding suggests that extended intergroup 
contact could shape the perception of appropriateness in intergroup contact, but it does necessarily lead to a more positive outgroup attitude. It might be attributable to the fact that the more fundamentalist group tends to hold a conservative moral value. Previous studies have shown that conservative morality concerns group loyalty, respect for authority, and bodily and spiritual purity (Haidt \& Graham, 2007). Here, a religious outgroup will be more likely to be regarded as a fixed entity that may harm or threaten ingroup values (Van Leeuwen \& Park, 2009). Therefore, even the norm indicates that intergroup contact is appropriate, outgroup attitude might not change. Moreover, as explained earlier, individuals in this type of group might be more likely to perceive fellow ingroup members involved in intergroup contact are outliers. Therefore, it will be less appropriate to conform.

Third, the findings in the context of the fundamentalist homogenous group showed that outgroup norms and intergroup anxiety mediated the relationship of extended intergroup contact and outgroup attitude. Ingroup norms did not mediate the relationship. This finding's novel contribution is intergroup contact's effectiveness in shaping positive outgroup norms and decreasing intergroup anxiety even in a more fundamentalist group. These findings imply that outgroup attitude in this group was more likely to be influenced by factors related to the interaction with outgroups (i.e., outgroup norms and intergroup anxiety) than factors related to ingroup (i.e., ingroup norms). This finding also indicates that extended intergroup contact could influence intergroup anxiety, while it was not the case in the more moderate group. One possible explanation is that individuals in a moderate group still have direct contact experiences, which might be negative. Importantly, we found that after controlling the role of direct intergroup contact, the significant mediating effect of intergroup anxiety was no longer significant, while the mediating effect of outgroup norms remained significant. This finding was consistent with study 1 and prior explanation: individuals also consider information from direct intergroup contact experiences in evaluating intergroup anxiety.

Finally, the inspection of the total effect coefficient revealed that $\mathrm{H} 10$ was supported. The total effect of extended intergroup contact on outgroup attitude was more extensive in a homogeneous group, particularly in a more fundamentalist religious school than in a heterogeneous group (i.e., public school) and the more moderate homogeneous school. It supports the notion that extended intergroup contact is more effective when direct intergroup contact is limited (Eller et al., 2012). Given that the total effect was smallest in the moderate religious school, this study further suggests that a moderate amount of direct intergroup contact might be detrimental for intergroup relationships. It could undermine the benefits of extended intergroup contact because people rely on a limited amount of direct intergroup contact experiences, which are more likely to be less favorable. 


\section{Conclusion}

Our results confirmed most of the hypotheses. A higher level of extended contact can indirectly predict the more positive intergroup attitudes via ingroup norms, outgroup norms, and intergroup anxiety. However, this pattern is not found in the highly homogenous groups' context: intergroup anxiety did not act as a mediator in a more moderate homogenous school; ingroup norms did not act as a mediator in a more fundamentalist homogenous school. More importantly, this study provides evidence that the mechanisms vary when direct intergroup contact is considered. These findings suggest that when available, individuals in either heterogeneous or homogenous are likely to employ information from direct intergroup contact than information from extended intergroup contact, particularly in intergroup anxiety.

Additionally, the present study suggests that individuals within the most heterogeneous group (i.e., public school) tend to be significantly different in key variables measured than those from Pesantren. They possess a more positive attitude toward outgroups, more frequent extended intergroup contacts, lesser intergroup anxiety, more positive ingroup norms, and more positive outgroup norms. These analyses support previous studies, which indicate a heterogeneous environment is important to promote positive intergroup relationships (e.g., Hewstone, 2009; Chris et al., 2010). Further, these studies suggest that extended intergroup contact is indeed beneficial for outgroup attitude across contexts. However, it does not mean that one could ignore the role of direct intergroup contact. The advantage of extended intergroup contact seems to be reduced when direct intergroup contact is negative. It is particularly important for the judgment on intergroup anxiety.

Finally, it can be inferred that outgroup norms were the only consistent mediator across contexts and situations. Meanwhile, ingroup norms and intergroup anxiety were relatively volatile, depending on homogeneity levels and direct intergroup contact experiences. Built on these findings, practitioners in intergroup contact might want to consider both extended and direct intergroup contact in their works. Although direct intergroup contact experience is limited, individuals might still employ information from these limited experiences to judge outgroup.

The present studies have provided meaningful findings, but we should note that future studies are needed to prove our claims more strongly. For example, we should examine the quality of extended contact and not just the mere frequencies of extended contact. Possibly, the quality of extended contact may also determine the ingroup norms or intergroup anxiety on the homogeneous groups. Second, it is also worth to directly examine whether the role of direct intergroup contact in extended intergroup contact will vary depending on the quality of the direct intergroup contact. As discussed in study 2, the mediating effect of intergroup anxiety was no longer significant after controlling the role of direct intergroup contact. Possibly, it is due to a negative direct intergroup contact experience. Third, it might also be interesting to examine different kinds of ingroup norms (injunctive and descriptive norms). As suggested by previous research (Yustisia, 2016), 
individuals will be more likely to rely on injunctive norms than descriptive norms in the context of intergroup relationships. Extended intergroup contact may affect the descriptive norms ("everybody does it"), but not injunctive norms ("everybody should do it"). Additionally, we should also examine whether the mechanisms found in this study would also be found in minority contexts - the prejudice effect is weaker for minorities than for majorities (Jasinskaja-Lahti et al., 2011).

\section{Implication}

Finally, we should also note several limitations to our studies. First, we did not measure the level of homogeneity of the groups. Moderate and fundamentalist Pesantren may be more similar than different. Second, we cannot establish the causal assumption firmly since we employed only cross-sectional and non-experimental researches. Thus, we cannot establish the claim of whether extended contact actually influences intergroup attitudes. Third, we should increase the number of participants to maximize external validity. Future studies should administer the data collections in more than one Pesantren for each group (heterogeneous and homogeneous).

\section{Acknowledgement}

The authors would like to express our special thanks to Research Assistants who had helped with data collection for this study: Afina R. Vinci, Gusti Ayu Ketut Vitha Adinda, Hana Paramytha, and Mufarridah Layalia. We also thank the teachers who had granted permission for us to visit the schools and administered the questionnaire.

\section{Funding}

This research was funded by Faculty of Psychology, University Indonesia under "Bantuan Dana Riset Mandiri Fakultas" scheme.

\section{Author's contribution}

WY built theoretical concepts, managing data collection, writing most part of the manuscripts. JH wrote some parts of discussion sections.

\section{Conflict of interests}

The authors declare that there is not conflict of interest in this research.

\section{Orcid ID}

Whinda Yustisia https://orcid.org/0000-0001-9684-8046

Joevarian Hudiyana https://orcid.org/0000-0001-5507-0573

\section{References}

Alesina, A., La Ferrara, E. (2005). Ethnic diversity and economic performance. Journal of Economic Literature, 43(3), 762- 800. https://doi.org/10.1257/002205105774431243.

Allport, G. W. (1954). The nature of prejudice. Cambridge, Masschusets. 
Arifianto, A. R. (2010). Islam and Christian - Muslim Relations Explaining the Cause of Muslim- Christian Conflicts in Indonesia: Tracing the Origins of Kristenisasi and Islamisasi Explaining the Cause of Muslim- Christian Conflicts in Indonesia: Tracing the Origins of Kristenisasi and Islamisasi. Islam and Christian-Muslim Relations, 20(1), 73-89. https://doi.org/10.1080/09596410802542144.

Aron, A., Aron, E. N., \& Smollan, D. (1992). Inclusion of Other in the Self Scale and the structure of interpersonal closeness. Journal of Personality and Social Psychology, 63(4), 596-612. https://doi.org/10.1037/0022-3514.63.4.596

Barlow, F. K.; Paolini, S.; Pedersen, A.; Hornsey, M. J.; Radke, H. R. M.; Harwood, J.; Rubin, M.; Sibley, C. G. (2012). "The contact caveat: Negative contact predicts increased prejudice more than positive contact predicts reduced prejudice". Personality and Social Psychology Bulletin. 38, 1629-1643. https://doi.org/10.1177/0146167212457953.

Cameron, L., Rutland, A., \& Brown, R. (2007). Promoting children's positive intergroup attitudes towards stigmatized groups: Extended contact and multiple classification skills training. International Journal of Behavioral Development, 31(5), 454-466. https://doi.org/10.1177/0165025407081474.

Cameron, L., Rutland, A., Brown, R., Douch, R. (2006) Changing children's intergroup attitudes towards refugees: Testing different models of extended contact. Child Development, 77(5), 1208-121. https://doi.org/10.1111/j.1467-8624.2006.00929.x.

Christ, O., Hewstone, M., Tausch, N., Wagner, U., Voci, A., Hughes, J., \& Cairns, E. (2010). Direct contact as a moderator of extended contact effects: Cross-sectional and longitudinal impact on outgroup attitudes, behavioral intentions, and attitude certainty. Personality and Social Psychology Bulletin, 36(12), 1662-1674. https://doi.org/10.1177/0146167210386969

Christ, O., Schmid, K., Lolliot, S., Swart, H., Stolle, D., \& Tausch, N. (2014). Contextual effect of positive intergroup contact on outgroup prejudice. Proceedings of the National Academy of Sciences, 111(11), 3996-4000. https://doi.org/10.1073/pnas.1320901111

Crandall, C. S. and Stangor, C. (2005) Conformity and prejudice. In J. F. Dovidio, P. Glick and L. A. Rudman(Eds), On the Nature of Prejudice: Fifty Years after Allport (pp. 295-310). Blackwell Publishing Ltd, Oxford, UK.

Degner, J., \& Dalege, J. (2013). The apple does not fall far from the tree, or does it? A metaanalysis of parent-child similarity in intergroup attitudes. Psychological Bulletin, 139(6), 1270-1304. https://doi.org/10.1037/a0031436

Dinesen, P. T., \& Sønderskov, K. M. (2012). Trust in a time of increasing diversity: On the relationship between ethnic heterogeneity and social trust in Denmark from 1979 until today. Scandinavian Political Studies, 35(4), 273-294. https://doi.org/10.1111/j.1467-9477.2012.00289.x

Dovidio, J. F., Eller, A., \& Hewstone, M. (2011). Improving intergroup relations through direct, extended and other forms of indirect contact. Group Processes $\mathcal{E}$ Intergroup Relations, 14(2), 147-160. https://doi.org/10.1177/1368430210390555 
Eller, A., Abrams, D., \& Gomez, A. (2012). When the direct route is blocked: The extended contact pathway to improving intergroup relations. International Journal of Intercultural Relations, 36(5), 637-646. https://doi.org/10.1016/j.ijintrel.2012.03.005

Forman, T. (2003). 'From pet to threat? Minority concentration, school racial context and white youths' racial attitudes.' Unpublished manuscript, University of Illinois at Chicago.

Hayes, A. F. (2009). Beyond Baron and Kenny: Statistical mediation analysis in the new millennium. Communication Monographs, 76(4), 408-420. https://doi.org/10.1080/03637750903310360

Haidt, J., \& Graham, J. (2007). When morality opposes justice: Conservatives have moral intuitions that liberals may not recognize. Social Justice Research, 20, 98-116. https://doi.org/10.1007/s11211-007-0034-z

Hewstone, M., \& Schmid, K. N. A. (2014). Neighbourhood ethnic diversity and orientations toward Muslims in Britain: The role of intergroup contact. The Political Quarterly, 85(3), 320-324. https://doi.org/10.1111/1467-923X.12098

Hewstone, M. (2009). Living apart, living together? The role of intergroup contact in social integration. MMG Working Paper 09-12 ISSN 2192-2357.

Hewstone, M., Clare, A., Newheiser, A. K., \& Voci, A. (2011). Individual and situational predictors of religious prejudice: Impact of religion, social dominance orientation, intergroup contact, and mortality salience. Testing, Psychometrics, Methodology in Applied Psychology, 18(3), 143-155.

Iannaccone, L. R., \& Berman, E. (2006). Religious extremism: The good, the bad, and the deadly. Public Choice, 128, 109-129. https://doi.org/10.1007/s11127-006-9047-7

Jasinskaja-Lahti, I., Mähönen, T. A., \& Liebkind, K. (2011). Ingroup norms, intergroup contact and intergroup anxiety as predictors of the outgroup attitudes of majority and minority youth. International Journal of Intercultural Relations, 35(3), 346-355. https://doi.org/10.1016/j.ijintrel.2010.06.001/

Kellow, C. L., \& Steeves, H. L. (1998). The role of radio in the Rwandan genocide. Journal of Communication, 48(3), 107-128. https://doi.org/10.1111/j.1460-2466.1998.tb02762.x

Lemmer, G., \& Wagner, U. (2015). Can we really reduce ethnic prejudice outside the lab? A meta-analysis of direct and indirect contact interventions. European Journal of Social Psychology, 45(2), 152-168. https://doi.org/10.1002/ejsp.2079

Liebkind, K., \& McAlister, A. L. (1999). Extended contact through peer modelling to promote tolerance in Finland. European Journal of Social Psychology, 29(5-6), 765-780. https://doi.org/10.1002/(SICI)1099-0992(199908/09)29:5/6<765::AIDEJSP958>3.0.CO;2-J

Lundgren, S. R., \& Prislin, R. (1998). Motivated Cognitive Processing and Attitude Change. Personality and Social Psychology Bulletin, 24(7), 715-726. https://doi.org/10.1177/0146167298247004

McLaren, L. M. (2003). Anti-immigrant prejudice in Europe: Contact, threat perception, and preferences for the exclusion of migrants. Social Forces, 81, 909-936. https://doi.org/10.1353/sof.2003.0038. 
Milla, M. N., \& Umam, A. N. (2019). Understanding intergroup contact on terrorist prisoners in Indonesia. Learning from violent extremist attacks: Behavioural sciences insights for practitioners and policymakers. World Scientific Press.

Mujiburrahman. (2006). Feeling threatened: Muslim-Christian relations in Indonesia's New Order. Amsterdam University Press.

Paolini, S., Hewstone, M., Cairns, E., \& Voci, A. (2004). Effects of direct and indirect crossgroup friendships on judgments of Catholics and Protestants in Northern Ireland: The mediating role of an anxiety-reduction mechanism. Personality and Social Psychology Bulletin, 30(6), 770-786. https://doi.org/10.1177/0146167203262848

Paolini, S., Harwood, J., \& Rubin, M. (2010). Negative intergroup contact makes group memberships salient: Explaining why intergroup conflict endures. Personality and Social Psychology Bulletin, 36(12), 1723-1738. https://doi.org/10.1177/0146167210388667

Pettigrew, T. F., Christ, O., \& Wagner, U. (2007). Direct and indirect intergroup contact effects on prejudice: A normative interpretation. International Journal of Intercultural Relations, 31, 411-425. https://doi.org/10.1016/j.ijintrel.2006.11.003

Pettigrew, T. F. (2009). Secondary transfer effect of contact: Do intergroup contact effects spread to noncontacted outgroups? Social Psychology, 40(2), 55-65. https://doi.org/10.1027/1864-9335.40.2.55

Putnam, R. D. (2007). E pluribus unum: Diversity and community in the twenty-first century the 2006 Johan Skytte Prize Lecture. Scandinavian Political Studies, 30(2), 137174. https://doi.org/10.1111/j.1467-9477.2007.00176.x

Sidel, J. T. (2007). The Islamist threat in Southeast Asia: a reassessment (Vol. 37). Institute of Southeast Asian.

Smith, J. R., \& Louis, W. R. (2009). Group norms and the attitude-behaviour relationship. Social and Personality Psychology Compass, 3(1), 19-35. https://doi.org/10.1111/j.17519004.2008.00161.x

Stephan, W. G., \& Stephan, C. W. (1985). Intergroup anxiety. Journal of Social Issues, 41(3), 157-175. https://doi.org/10.1111/j.1540-4560.1985.tb01134.x

Sterkens, C. J. A., \& Hadiwitanto, H. (2009). From social to religious conflict in Ambon. An analysis of the origins of religiously inspired violence. In Sterkens, C.; Machasin, M. (ed.), Religion, civil society and conflict in Indonesia (pp. 59-86). Lit Verlag

Stolle, D., Soroka, S., \& Johnston, R. (2008). When does diversity erode trust? Neighborhood diversity, interpersonal trust and the mediating effect of social interactions. Political Studies, 56(1), 57-75. https://doi.org/10.1111/j.14679248.2007.00717.x

Tam, T., Hewstone, M., Kenworthy, J., \& Cairns, E. (2009). Intergroup trust in Northern Ireland. Personality and Social Psychology Bulletin, 35(1), 45-59. https://doi.org/10.1177/0146167208325004

Taylor, M. C. (1998). How White attitudes vary with the racial composition of local populations: Numbers count. American Sociological Review, 63(4), 512-535. https://doi.org/10.2307/2657265 
Tropp, L. R., Hawi, D. R., Laar, C. Van, \& Levin, S. (2012). Cross-ethnic friendships, perceived discrimination, and their effects on ethnic activism over time: A longitudinal investigation of three ethnic minority groups. British Journal of Social Psychology, 51, 257-272. https://doi.org/10.1111/j.2044-8309.2011.02050.x

Turner, R. N., Hewstone, M., Voci, A., \& Vonofakou, C. (2008). A test of the extended intergroup contact hypothesis: The mediating role of intergroup anxiety, perceived ingroup and outgroup norms, and inclusion of the outgroup in the self. Journal of Personality and Social Psychology, 95(4), 843-860. https://doi.org/10.1037/a0011434

Turner, R. N. Hewstone, M., Paolini, S., Christ, O. (2007). Reducing prejudice via direct and extended cross-group friendship. European Review of Social Psychology, 18(1), 212-255. https://doi.org/10.1080/10463280701680297

Turner, R. N., Crisp, R. J., \& Lambert, E. (2007). Imagining intergroup contact can improve intergroup attitudes. Group Processes \& Intergroup Relations, 10(4), 427-441. https://doi.org/10.1177/1368430207081533

van Leeuwen, F., \& Park, J. H. (2009). Perceptions of social dangers, moral foundations, and political orientation. Personality and Individual Differences, 47(3), 169-173. https://doi.org/10.1016/j.paid.2009.02.017

Wagner, U., Christ, O., Pettigrew, T. F., Stellmacher, J., \& Wolf, C. (2006). Prejudice and minority proportion: Contact instead of threat effects. Social Psychology Quarterly, 69(4), 380-390. https://doi.org/10.1177/019027250606900406

Wilder, D. \& Simon, A. (2001) Affect as a cause of intergroup bias. Blackwell Handbook of Social Psychology: Intergroup Processes, 153-172. Willey Online Library.

Wood, W. (2000). Attitude change: Persuasion and social influence. Annual Review Psychology, 51, 539-570. https://doi.org/10.1146/annurev.psych.51.1.539

Wright, S. C., Aron, A., McLaughlin-Volpe, T., \& Ropp, S. A. (1997). The extended contact effect: Knowledge of cross-group friendships and prejudice. Journal of Personality and Social Psychology, 73(1), 73-90. https://doi.org/10.1037/0022-3514.73.1.73

Wright, S. C., Aron, A., \& Brody, S. M. (2008). Extended contact and including others in the self: Building on the Allport/Pettigrew legacy. In U. Wagner, L. R. Tropp, G. Finchilescu, \& C. Tredoux (Eds.), Social issues and interventions. Improving intergroup relations: Building on the legacy of Thomas F. Pettigrew (p. 143-159). Blackwell Publishing. https://doi.org/10.1002/9781444303117.ch10

Yustisia, W. (2016). Group norms as moderator in the effect of cross group friendship on outgroup attitude: A study on interreligious group in Indonesia. Makara Hubs-Asia, 20(1), 57-66. https://doi.org/10.7454/mssh.v20i1.3487

Yustisia, W., Shadiqi, M. A., Milla, M. N., \& Muluk, H. (2020). An investigation of an Expanded Encapsulate Model of Social Identity in Collective Action (EMSICA) including perception of threat and intergroup contact to understand support for Islamist terrorism in Indonesia. Asian Journal of Social Psychology, 23, 29-41. https://doi.org/10.1111/ajsp.12372. 